\title{
Rancang Bangun Virtual Laboratory Pemuaian untuk SMP
}

\author{
Novi Nurhayati ${ }^{1, a)}$, Ijang Rohman ${ }^{2, b)}$ \\ ${ }^{1}$ Sekolah Pasca Sarjana Universitas Pendidikan Indonesia, Bandung 40154 \\ ${ }^{2}$ Universitas Pendidikan Indonesia, Bandung 40154 \\ Email: a)novi83suyatno@gmail.com, ${ }^{\text {b) } i j a n g r h @ g m a i l . c o m ~}$
}

\begin{abstract}
This paper describes the development of Virtual Laboratory for simulation lab expansion (VLExpansion) at Junior High School (SMP). The reason of building VL- Expansion is the demands science teaching in the schools which are able to construct mastery of concepts and critical thinking skills within an effective and an efficient. Based on the preliminary studies in several junior high school in Bandung found that: 1) the number of tools to support the expansion practicum available in laboratories is still limited, 2) practical implementation of such material is infrequency performed, while the practical implementation can build mastery of concepts and critical thinking skills. On the other hand, schools (SMP) have a lots of the computer lab facilities. Nevertheless, in fact it was never done for the science lab. The development steps were conducted, there were: 1) analysis of the concept and indicators of critical thinking skills, 2) analysis of the working principle Muschenbroek, 3) extracting the fundamental concepts and phenomena of expansion for various metals, 4) design prototypes VL- Expansion. Thus, the results of the test to the teachers revealed that the VL-Expansion is feasible to be used to construct mastery of concepts and critical thinking skills junior high school students.
\end{abstract}

Keywords: design, virtual laboratory, expansion

\begin{abstract}
Abstrak
Makalah ini memaparkan pengembangan Virtual Laboratory untuk simulasi praktikum pemuaian (VL-Pemuaian) di Sekolah Menengah Pertama (SMP). VL-Pemuaian dibangun karena kebutuhan dalam pembelajaran IPA di sekolah yang mampu membangun penguasaan konsep dan kemampuan berpikir kritis yang efektif dan efisien. Berdasarkan studi pendahuluan di beberapa SMP di kota Bandung diperoleh bahwa: 1) jumlah alat untuk mendukung praktikum pemuaian yang tersedia di laboratorium masih terbatas, 2) pelaksanaan praktikum untuk materi tersebut jarang dilakukan, sedangkan pelaksanaan praktikum dapat membangun penguasaan konsep dan kemampuan berpikir kritis. Di sisi lain, sekolah-sekolah (SMP) sudah banyak yang memiliki fasilitas laboratorium komputer. Namun kenyataannya tidak pernah dilakukan untuk praktikum IPA. Langkah pengembangan yang dilakukan meliputi: 1) analisis konsep dan indikator keterampilan berpikir kritis, 2) analisis prinsip kerja Muschenbroek, 3) penggalian konsep dasar dan fenomena pemuaian untuk berbagai logam, 4) rancang bangun prototipe VL-Pemuaian. Dari hasil uji coba pada guru diperolah hasil bahwa VL-Pemuaian ini layak untuk digunakan untuk membangun penguasaan konsep dan kemampuan berpikir kritis siswa SMP.
\end{abstract}

Kata-kata kunci: rancang bangun, virtual laboratory, pemuaian 


\section{PENDAHULUAN}

Praktikum merupakan metode pembelajaran yang penting dalam pembelajaran IPA. Praktikum dapat memberikan pengalaman langsung kepada siswa untuk memperkenalkan, membiasakan, dan melatih siswa untuk melaksanakan langkah-langkah ilmiah dan pengetahuan prosedural. Selain untuk memahami konsep, praktikum atau eksperimen juga berdampak positif terhadap peningkatan motivasi dan minat belajar siswa (Mulyani 2005; Pulaila 2007; Rustaman 2005)

Berdasarkan hasil studi pendahuluan di salah satu SMPN 22 Bandung, kegiatan praktikum di sekolah jarang dilakukan, karena beberapa hal yaitu:

1. Jumlah alat praktikum yang tidak memadai, jumlah alat terbatas, dan banyak alat yang sudah rusak

2. Tidak terdapat laboran, yaitu SDM khusus yang ahli di bidang penggunaan dan pemeliharaan alat

3. Minimnya pelatihan berkala bagi guru untuk meningkatkan kemampuan dalam melakukan praktikum di laboratorium

Salah satu kendala yang biasa muncul pada pelaksanaan metode eksperimen adalah alat eksperimen yang terbatas dan waktu yang relatif lama untuk kegiatan eksperimen (praktikum). Hal ini sesuai dengan penelitian Widodo $(2005 ; 10)$ bahwa alasan terbanyak yang dikemukakan oleh guru-guru terkait dengan kegiatan praktikum adalah kurangnya waktu yang dibutuhkan untuk mengelola sebuah praktikum, alat-alat yang belum tersedia, terlalu merepotkan dan kurang terampilnya guru dalam melakukan pengelolaan waktu. Akibatnya kegiatan praktikum jarang dilakukan sekolah-sekolah.

Konsep pemuaian merupakan konsep yang penting dalam IPA. Konsep ini terdapat dalam Kompetensi dasar nomor 3.7 dalam kurikulum IPA di SMP. Namun kemampuan penguasaan konsep pemuaian siswa masih rendah. Hal ini terlihat dari hasil ulangan harian yang masih di bawah KKM (Kriteria Ketuntasan Minimum). Sepuluh dari tiga puluh lima nilai ulangan harian siswa masih di bawah KKM.

Terdapat keterbatasan pelaksanaan praktikum pemuaian dengan menggunakan alat nyata. Pada praktikum pemuaian logam dengan menggunakan alat Musschenbroek terdapat peluang kecelakaan. Hal ini karena pada alat tersebut digunakan api untuk memanaskan beberapa jenis logam, sedangkan keterampilan awal siswa dalam menggunakan alat masih sangat kurang sehingga terjadi peluang kecelakaan. Alat Mushenbroek nyata hanya memuat tiga jenis logam yang sudah ditentukan oleh cetakan pabrik. Untuk menambah jenis logam yang dapat diamati pada alat ini membutuhkan ketelitian dan dana yang cukup besar. Namun keterbatasan alat Muschenbroek tersebut dapat diminimalkan dengan menghadirkan VL pemuaian sebagai pelengkap alat Muschenbroek nyata. Dengan menggunakan VL, maka jenis logam yang dibandingkan dapat lebih banyak dan bervariasi. Kegiatan praktikum dapat lebih efektif karena dapat diperoleh data yang lebih banyak dalam waktu yang relatif singkat.

Virtual lab merupakan alternatif fasilitas yang dapat digunakan dalam kegiatan belajar mengajar terutama pada materi bahan ajar yang menggunakan alat yang dinilai mengandung resiko kecelakaan kerja. Selain itu, virtual lab juga bisa menjadi alternatif bagi sekolah yang hanya memiliki jumlah alat yang terbatas.

Beberapa penelitian tentang virtual lab telah dilakukan. Manisha Bajpai mengungkapkan bahwa Penggunaan Laboratorium Virtual dapat meningkatkan penguasaan konsep siswa dibandingkan siswa yang menggunakan Laboratorium Nyata (Manisha Bajpai/2012). Necati Taukon mengungkapkan bahwa Pembelajaran dengan simulasi berbasis komputer meningkatkan prestasi akademik dan keterampilan belajar siswa (Necati TaúkÕn, Bülent Kandemir/2010). Penelitian serupa juga dinyatakan oleh Aucharaporn Gunhaart mengungkapkan bahwa Siswa yang belajar menggunakan metodologi campuran antara Microcomputer-Based Laboratory (MBL) dan simulasi komputer memiliki nilai yang lebih tinggi pada hasil posttest dibandingkan pretest, hal ini menunjukkan bahwa MBL meningkatkan pemahaman konseptual siswa (Audcharaporn Gunhaart, Niwat Srisawasdi/2012). Berdasarkan hasil penelitian penggunaan laboratorium secara virtual dapat meningkatkan penguasaan konsep, keterampilan proses sains (KPS) siswa, dan kemampuan berpikir 
siswa (Zacharia \& Anderson, 2003; Yang \& Jia-Sheng, 2007; Cobb et la.,2009; Franklin et la., 2001; Abdullah \& Shariff, 2008; Subiantoro, 2008)

Kemampuan lain dari VL-pemuaian selain membangun penguasaan konsep adalah dapat membangun kemampuan berpikir kritis siswa. Hasil penelitian yang telah dilakukan, Pembelajaran berbasis praktikum virtual dapat meningkatkan kemampuan berpikir kritis dan sikap ilmiah siswa SMP (Dini ; 2012). Sesuai dengan hal itu, kegiatan praktikum dapat meningkatkan kemampuan berpikir kritis siswa, pemahaman konsep dan sikap ilmiah siswa (Ika; 2012)

Penguasaan konsep menurut dahar (2003) adalah kemampuan siswa dalam memahami makna pembelajaran dan mampu menerapkannya dalam kehidupan sehari-hari. Dengan kata lain penguasaan konsep adalah selain siswa memahami pembelajaran juga mampu menjawab permasalahan yang ditemukannya di kehidupan sehari-hari

Berpikir kritis menurut Jhonson (2011) merupakan proses yang terarah dan jelas yang digunakan dalam kegiatan mental seperti memecahkan masalah, mengambil keputusan, membujuk, menganalisis asumsi, dan melakukan penelitian ilmiah. Berpikir kritis adalah kemampuan berpendapat dengan cara yang terorganisasi

Norris dan Ennis (1989; dalam Stiggins, 1994) menyatakan bahwa berpikir kritis merupakan berpikir masuk akal yang difokuskan pada pengambilan keputusan tentang apa yang dilakukan dan diyakini. Masuk akal berarti berpikir didasarkan atas fakta-fakta untuk menghasilkan keputusan yang terbaik, sedangkan reflektif berarti mencari dengan sadar dan tegas kemungkinan solusi yang terbaik. Dengan demikian menurut Rustaman (2005) berpikir kritis adalah mengevaluasi tindakan atau keyakinan yang terbaik

Berdasarkan uraian tersebut, perlu dilakukan Penelitian Pengembangan Virtual Lab Pemuaian untuk Meningkatkan Penguasaan Konsep Dan Kemampuan Berpikir Kritis Siswa. Tujuan dari penelitian ini adalah Untuk menghasilkan produk pengembangan virtual laboratory pada materi pemuaian yang dapat digunakan oleh siswa SMP.

\section{METODE PENELITIAN}

Jenis penelitian yang digunakan adalah Penelitian pengembangan (Research and Development). Metode penelitian pengembangan atau dalam bahasa Inggris Research And Development adalah metode penelitian yang digunakan untuk menghasilkan produk tertentu, dan menguji keefektifan produk tersebut. Dalam hal ini produk berupa software VL pemuaian.

Untuk dapat menghasilkan produk VL pemuaian digunakan penelitian yang bersifat analisis kebutuhan dan untuk menguji keefektifan produk tersebut supaya dapat berfungsi di masyarakat luas, maka diperlukan penelitian untuk menguji keefektifan produk tersebut.

Pada penelitian ini populasi adalah guru SMPN 22 Bandung, sedangkan sampel adalah guru kelas VII SMPN 22 Bandung. Langkah pengembangan yang dilakukan meliputi: 1) analisis konsep dan indikator keterampilan berpikir kritis 2) analisis prinsip kerja Muschenbroek 3) penggalian konsep dasar dan fenomena pemuaian untuk berbagai logam 4) rancang bangun prototipe VL-Pemuaian.

Pembuatan program VL-Pemuaian meliputi pembuatan story Board dan coding data. Pembuatan story Board dilakukan oleh penulis, sedangkan coding data diserahkan kepada ahli Programmer. Pembuatan story Board dan coding data dilakukan selama empat bulan, yaitu sejak 1 januari hingga 30 April 2015. Story Board mengalami proses pengembangan sampai delapan versi. Sedangkan coding data mengalami perbaikan sebanyak lima kali.

Setelah VL-Pemuaian selesai dibangun, dilakukan evaluasi program berkaitan dengan kesesuaian story Board dengan produk penelitian berupa VL-Pemuaian. Apabila ditemukan ketidak sesuaian, dilakukan revisi program VL-Pemuaian . Selanjutnya dilakukan uji coba terbatas kepada dua orang guru IPA di SMPN 22 Bandung.

Instrumen yang digunakan pada penelitian ini meliputi:

1. Lembar penilaian Ahli Media bertujuan untuk mendapatkan gambaran penilaian tentang desain VL yang telah dikembangkan.

2. Lembar penilaian Ahli Konten bertujuan untuk mendapatkan gambaran penilaian tentang desain VL yang telah dikembangkan.

3. Angket penilaian VL-Pemuaian oleh guru sebagai pengguna. 


\section{HASIL DAN PEMBAHASAN}

Hasil dari penelitian ini berupa produk VL-Pemuaian yang dibangun menggunakan program flash untuk digunakan di SMP. Berikut ini merupakan tampilan hasil rancang banmgun VL-Pemuaian.

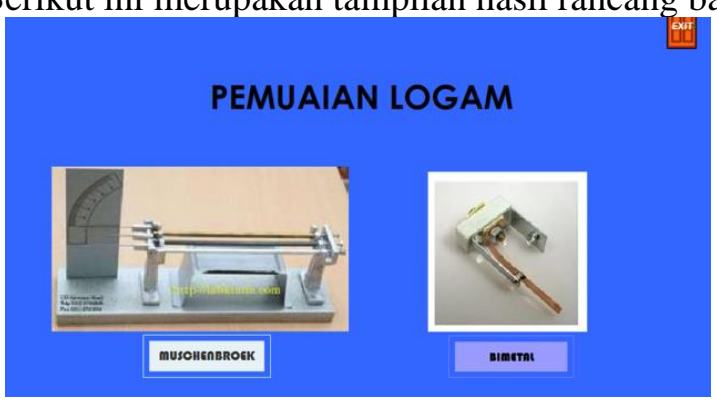

GAMBAR 1. Layar home VL-Pemuaian

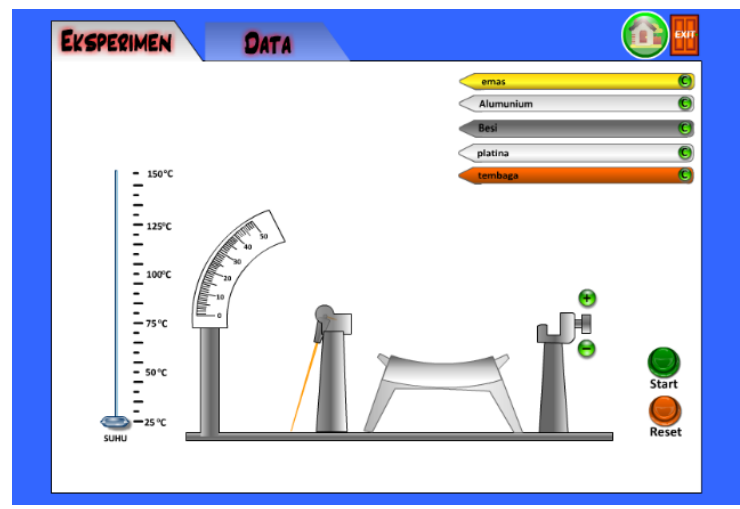

GAMBAR 2. Layar praktikum Muschenbroek

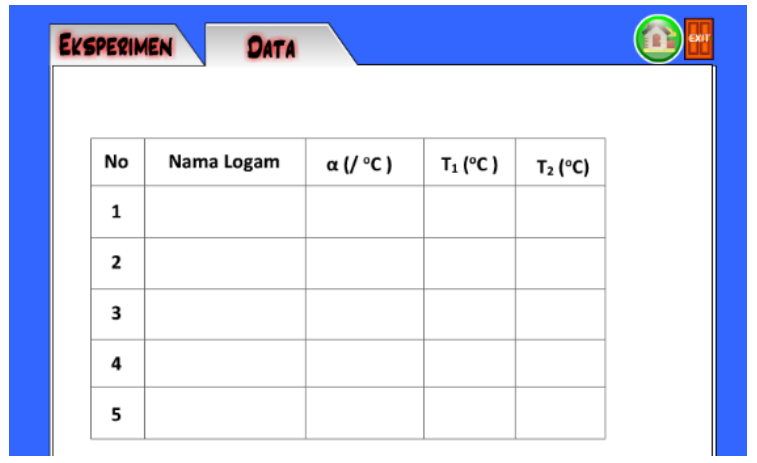

GAMBAR 3. Layar rekap data praktikum Muschenbroek

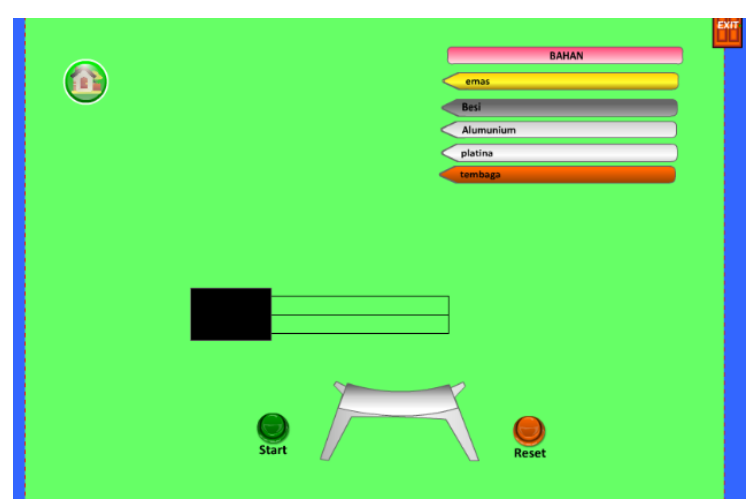

GAMBAR 4. Layar praktikum bimetal 
Hasil validasi ahli media menyatakan bahwa sistem navigasi VL-Pemuaian sudah baik dan mudah untuk digunakan. Proses login dapat dilakukan dengan mudah, menu praktikum berfungsi baik, tombol Drag berfungsi baik, pengatur jarum skala berfungsi baik, tombol api berfungsi baik, serta skala suhu dapat terlihat jelas. Tombol reset berfungsi baik, perpindahan dari menu praktikum satu ke menu data mudah, serta perpindahan dari menu praktikum satu ke praktikum dua mudah. Desain grafis VL-Pemuaian sudah layak digunakan. Teks dapat dibaca dengan jelas, ukuran huruf seimbang dengan layar, serta paduan warna tidak menyiaukan mata

Hasil judgmen dari ahli konten menyatakan bahwa VL-Pemuaian memiliki prinsip kerja sesuai dengan alat yang sesuungguhnya. VL-Pemuaian sesuai dengan konsep pemuaian logam yang berlaku meliputi: 1) Pemuaian logam, 2) Perbedaan pemuaian pada beberapa logam, serta 3) pemuaian pada bimetal.

Hasil judgmen dari guru sebagai pengguna menyatakan bahwa VL-Pemuaian dapat membangun penguasaan konsep Pemuaian Logam. Hal ini karena VL-Pemuaian dapat digunakan untuk menemukan fenomena pemuaian logam, dapat digunakan untuk membandingkan perbedaan pemuaian pada setiap logam, serta dapat digunakan untuk menemukan fenomena bimetal saat dipanaskan.

Selain itu, VL-Pemuaian dapat membangun kemampuan berpikir kritis siswa. Hal tersebut karena VL-Pemuaian dapat memfasilitasi siswa untuk bertanya dan menjawab pertanyaan tentang pemuaian logam. VL-Pemuaian dapat memfasilitasi siswa melakukan pengamatan pemuaian logam. Selain itu data hasil percobaan VL-Pemuaian dapat mendukung perumusan konsep dan prinsip pemuaian. Selanjutnya VL-Pemuaian dapat membantu siswa mendapatkan cara dan menentukan tindakan berhubungan dengan masalah pemuaian logam di kehidupan sehari-hari.

\section{KESIMPULAN}

Berdasarkan angket penilaian pada uji coba penggunaan VL-Pemuaian oleh guru diperolah hasil bahwa:

1. VL-Pemuaian sesuai dengan alat sesungguhnya

2. VL-Pemuaian sesuai dengan konsep yang berlaku

3. Sistem navigasi VL-Pemuaian baik

4. Desain grafis VL-Pemuaian baik

Berdasarkan angket analisis kemampuan VL-Pemuaian, dapat diketahui bahwa:

1. VL-Pemuaian dapat digunakan untuk menemukan fenomena pemuaian logam

2. VL-Pemuaian dapat digunakan untuk membandingkan perbedaan pemuaian pada setiap logam

3. VL-Pemuaian dapat digunakan untuk menemukan fenomena bimetal saat dipanaskan.

4. VL-Pemuaian dapat memfasilitasi siswa bertanya dan menjawab pertanyaan tentang pemuaian logam

5. VL-Pemuaian dapat digunakan untuk pengamatan pemuaian logam.

Berdasarkan angket penilaian tersebut maka dapat ditarik kesimpulan bahwa VL-Pemuaian layak digunakan di SMP. VL-Pemuaian dapat digunakan membangun penguasaan konsep dan membangun kemampuan berpikir kritis siswa.

\section{UCAPAN TERIMAKASIH}

Ucapan terima kasih kepada Programmer VL-Pemuaian bapak Muhammad Irsyad,S.Pd.; guru IPA pengguna VL-Pemuaian ibu Tasliah,S.Pd dan bapak Deni Heryanto,S.Pd; serta semua pihak yang telah mendukung penyelesaian makalah ini. 


\section{REFERENSI}

Audcharaporn Gunhaart (2012), Effect of integrated compute-based laboratory environment on student physics conceptual learning of sound waves properties WCES Procedia 46 ( 2012 ) 5750 5755.

Asniar, (2012), Efektifitas pembelajaran IPA terpadu model connected untuk meningkatkan aliterasi sains siswa kelas VIII pada tema rokok dan kesehatan, Tesis pada PPs UPI. Bandung: Tidak diterbitkan.

Dini Sri, (2012), Penerapan pembelajaran sistem sirkulasi berbasis virtual untuk meningkatkan kemampuan berpikir kritis dan sikap ilmiah siswa SMP, Tesis pada PPs UPI. Bandung: Tidak diterbitkan.

Ika Siti, (2012), Pengaruh praktikum virtual pada konsep sistem saraf terhadap perkembangan kemampuan berpikir kritis, pemahaman konsep, dan sikap ilmiah siswa kelas IX, Tesis pada PPs UPI. Bandung: Tidak diterbitkan.

Kemendikbud. (2013). Materi Pelatihan Guru Implementasi Kurikulum 2013. Jakarta: Badan Pengembangan Sumber Daya Manusia Pendidikan dan kebudayaan dan penjaminan Mutu pendidikan Kementrian Pendidikan dan kebudayaan.

Kemendikbud. (2013). Ilmu Pengetahuan Alam Kelas 7. Jakarta: Kemendikbud RI.

Manisha Bajpai (2013) Developing Concepts in Physics Through Virtual Lab Experiment: An Effectiveness Duden Saepuzaman, (2011) Penerapan Model Pembelajaran Inkuiri Dengan Kombinasi Eksperimen Nyata-Virtual Pada Materi Rangkaian Listrik Arus Searah Untuk Meningkatkan Penguasaan Konsep Dan Penguasaan konsep Siswa SMA, Tesis pada PPs UPI. Bandung: Tidak diterbitkan.

Necati TaúkÕn (2010) The affect of computer supported simulation applications on the academic achievements and attainments of the seventh grade students on teaching of science WCLTA Procedia 9 (2010) 1379-1384.

Stiggins, Richard J (1994), Student-Centered Classroom Assessment, Macmillan College, Study Techno LEARN: 3 (1): 43-50.

Sugiono, (2011) Metode Penelitian Pendidikan Pendekatan kuantitatif, kualitatif dan R\&D, Alfabeta.

Surya Gumilar (2013) Penerapan model pembelajaran inkuiri dengan kombinasi metode eksperimen nyata-virtual untuk meningkatkan pemahaman konsep dan keterampilan berpikir kritis, Tesis pada PPs UPI. Bandung: Tidak diterbitkan.

Syabaniah Ratna. (2011) Penggunaan Laboratorium Nyata, Virtual, Dan Kombinasi Nyata-Virtual Pada Kegiatan Praktikum Kultur Jaringan Untuk Meningkatkan Penguasaan Konsep Dan Penguasaan konsep, Tesis pada PPs UPI. Bandung: Tidak diterbitkan. 